\title{
Muhammadiyah's Educational Philanthropy Movement in North Kolaka
}

\author{
Muhammad Alifuddin ${ }^{1}$, Suarni $^{2}$, Nurjannah ${ }^{3}$ \\ ${ }^{1}$ Syari'ah Faculty and Law of IAIN Kendari \\ Email: proposalalif@gmail.com \\ ${ }^{2}$ Faculty of Islam of Universitas Muhammadiyah Kendari \\ Email: ummy_pai@yahoo.co.id \\ ${ }^{3}$ Faculty of Islamic Economics and Business of IAIN Kendari \\ Email: nurjannahnur76@gmail.com
}

\begin{abstract}
This study aims to provide an analytical view of the Muhammadiyah Education Philanthropy Movement in North Kolaka. The research data was obtained through a series of in-depth interviews, observations and document studies. All data obtained was assessed in stages using the Miles and Huberman analysis models. Based on data's found in the field of research, the Muhammadiyah educational philanthropy movement has existed in this region since 1968. The Muhammadiyah philanthropy movement in North Kolaka is a social fact that is inevitable to be appreciated. Imagine, the movement of social movements has been present in a social space that was historically geographically isolated and prone to historically political politics. In such limited conditions, in a period where the eyes of social movements are generally still "quiet" asleep and while the hands of devotion are still rigidly grasped, Muhammadiyah with all its limitations greets the hopes of rural children who are far from educational services, in order to provide formula of literacy as the solution to the thirst for education that they feel and never felt before. Muhammadiyah's ability to fulfill literacy expectations for a number of rural children during the period of education scarcity in North Kolaka which continues to this day, such a nice result of collective sincerity after all. The construction of collective excitement is channeled philanthropically by the Muhammadiyah community on the foundation of humanitarian principles that are rahmatanlilalamin, with one common goal, namely; enrich the life of a nation. These efforts in the political context can be interpreted as wordless nationalism, which is very rarely filtered through proclamation but
\end{abstract}


lives in reality. However, along with the development and stretching of the era that influenced the management of educational institutions, Muhammadiyah was also demanded to immediately revitalize the management of its educational institutions in North Kolaka, if it did not want to become a historical fossil.

\section{Keywords: Philantrophy, Education and Muhammadiyah}

\section{Introduction}

In the historical record of the revival citizen of Southeast Sulawesi, Muhammadiyah is mentioned as one of the three social movements that has a stake in raising nationalism awareness of the local community. ${ }^{1}$ Muhammadiyah social movements that stood out in the early days of the national revival were preaching and education. Through the educational institution he built, Muhammadiyah listed itself in Southeast Sulawesi as the social organization of the forefront of the era before independence, which dedicated it's devoted charity to educating the children of the Archipelago living in isolated areas. North Kolaka, which now stands as a separate Regency geographically, is at the northernmost tip of Sulawesi-Southeast which borders directly with South of Sulawesi. Before separated and standing alone, this region was an integral part of Kolaka Regency. Until the end of the 1980s the area was still very isolated due to the absence of an overland road that could connect between Lasusua District (now as the center of North Kolaka City) and Kolaka Regency. This condition is an obstacle for the local community to develop the potential of their minds.

If in the period until the late 1980s the condition of the region was still isolated, the proper question then was how in the period before that period. In terms of history, this area is not only inhabited by local people but also inhabited by the Bugis community who migrated from Luwu, long before the independence era. ${ }^{2}$ So in these

${ }^{1}$ In the early days of the formation of national consciousness in Sulawesi Tenggara, there were three organizations that were instrumental in moving national awareness, namely: Muhammadiyah, PSI and Parindra. Read, among others: Tim Depdikbud. (1978). Sejarah Kebangkitan Nasional Daerah Sulawesi Tenggara, (Jakarta: Depdikbud), p. 103

${ }^{2}$ Mudawing, one of the writer's informants, mentioned that the Bugis community who inhabited this area had existed since the 30 s, generally a party of 
conditions you can imagine what about education services for the local community. It can be ascertained that the period before independence until the early post-independence period the condition of educational institutions in the region is still very limited and thus has implications for their socio-cultural conditions. Interestingly, at that time the Muhammadiyah education movement penetrated into the area, as if answering the hopes of the local community for their needs for education. In this context, this paper will not only describe the footsteps of the Muhammadiyah Education Philanthropy Movement in North Kolaka, as well as describe how the philanthropy movement pattern developed by Muhammadiyah and it's sustainability until this day.

Studies on the existence of the Muhammadiyah movement in all it's dimensions have been carried out by researchers, both by domestic academics and by those from outside. The extent of the arable land from Muhammadiyah's religious social movements, makes studies related to Muhammadiyah also more diverse. Relevant Studies related to Muhammadiyah's educational philanthropy movements as the focus of this study have also been carried out by several researchers, including: Mafidin, Literature Studies on the Role of Muhammadiyah in Developing Islamic Education in Indonesia. Mafidin concluded that Muhammadiyah's education could develop throughout the country, not only because of the governance system that uses modern management, but also because all the Muhammadiyah's educational charitable endeavors became fully the organizational assets. Muhammadiyah's commitment to advancing the world of education is evidenced by the growing growth of Muhammadiyah educational institutions in the country. ${ }^{3}$ A research similar to Mafidin, conducted by Syamsul Huda: MuhammadiyahAs an Educational Movement. As with previous research, Huda also concluded that Muhammadiyah was present as an educational movement that had colored the course of national education from it's inception until now.Because it is not excessive when the government gives appreciation to the Muhammadiyah organ

Luwu people who migrated as a result of their disagreement with King Luwu at that time. Interview

${ }^{3}$ Mafidin. (2012). Literature Study on the Role of Muhammadiyah in Developing Islamic Education in Indonesia, Jurnal Tarbawi, Vol.1, No.1, p.53 
and the founder his self KH.Ahmad Dahlan for his legacy and dedication to the country as one of the national heroes. ${ }^{4}$

There are still a number of studies related to the Muhammadiyah education movement, one of which is research, Abdul Alimun Utama: History and Development of Muhammadiyah Educational Institutions in Sumbawa Regency, West Nusa Tenggara in 1940-2014. Utama said that historically Muhammadiyah had provided education services to the people of Sumbawa since 1952. The presence of Muhammadiyah with it's educational institutions in the region, was very supportive for the development of Islamic educational institutions through formal, non-formal and informal channels. The factors that greatly affect the success of the Sumbawa Muhammadiyah organization in developing Muhammadiyah educational institutions can be seen from several internal and external factors, namely schools, human resources, and educational tools. Whereas the most important inhibiting factor is the funding factor which is an ongoing asset of an education, and is strongly rivaled by state education institutions. ${ }^{5}$ Nelly Yusra: Muhammadiyah: Education Reform Movement, as the Main article, Yusra also marked the importance of Muhammadiyah to immediately conduct revitalization in the context of management of the educational institutions it manages by his self, this becomes very important given the intense competition in the "business" of the education world. ${ }^{6}$ There are still a number of studies related to the history of the Muhammadiyah education movement, but from a number of writings by the inventory authors there is no specific study of the movements of Muhammadiyah philanthropy in the North Kolaka region as will be examined in this research.

\section{Method}

This research is analytic descriptive by using qualitative data's. The whole data in this study were obtained through a series of

\footnotetext{
${ }^{4}$ Syamsul Huda. (2019). Muhammadiyah Sebagai Gerakan Pendidikan,TARLIM JurnalPendidikan Islam, Vol.2, No. 2.

${ }^{5}$ Abdul Alimun Utama. (2017). Sejarahdan Perkembangan Lembaga Pendidikan Muhammadiyah di Kabupaten Sumbawa Nusa Tenggara Barat tahun 1940-2014, PROFETIKA JurnalStudi Islam, Vol. 18, No.1.

${ }^{6}$ Nelly Yusra. (2018). Muhammadiyah: Gerakan Pembaharuan Pendidikan, POTENSIA, Jurnal Kependidikan Islam, No. 1, Vol. 4.
} 
in-depth interviews with a number of informants consisting of community leaders, religious leaders and all parties related to this research. In addition to interviews, data were obtained through observation and study of a number of documents. The data collected is then analyzed based on the Miles and Huberman method. ${ }^{7}$

\section{Data Description}

\section{A Glimpse of North Kolaka}

Kolaka Utara is a regency located in the northernmost part of Southeast Sulawesi, bordering Luwu Regency in South Sulawesi in the east and in the south bordering Kolaka Regency in Southeast Sulawesi and in the west bordering Bone Bay. The district's main sources of income are cocoa, coconut and clove plantations. About $80 \%$ of the population of this district depends on plantations to fulfill their life. The people who have settled in the northern part of Kolaka Regency since the 1960s have actually tried to bring new districts in line with changes in the political system with the formation of districts and provinces. However, the central government policy stipulates that the northern part of Kolaka Regency, also known as "Patowanua" (meaning 4 areas that are united, namely; wonuaLewawo, wonuaLato, wonuaWatunohu, and wonuaKodeoha) "are included in the territory of Kolaka Regency. ${ }^{8}$ Efforts or ideals of the people in this region to grow and develop independently in a particular district area, achieved in 2003, precisely on December 18, 2003 with the birth of Law No. 29 of 2003 concerning regional expansion, this region was officially separated from Kolaka region became a separate area that is now known by the name of North Kolaka Regency.

\section{1) Muhammadiyah Educational Institutions in North Kolaka}

Since the beginning of its existence, Muhammadiyah has proclaimed itself as a preaching and social organ that is engaged in the realm of education, health and services for groups of two through an orphanage. In the education sector Muhammadiyah has thousands of business charities in the field of education ranging from kindergarten,

7 Matthew B. Miles \&Huberman. (1986). Qualitatif Data Analysis: A Sourcebook of New Method, (Baverly Hills: Sage Publication), p. 20

${ }^{8}$ https://www.kolutkab.go.id/sejarah-kolaka-utara, mengenallatarsejarah, namadanBahasa, suku di kolakautara 
elementary / Ibtidaiyah, junior / Tsanawiyah, high school / Aliyah, Islamic boarding school, anduniversity. In Southeast Sulawesi Muhammadiyah at least manages 52 educational institutions at all levels. Of course, this amount is very small when compared to the charitable efforts of Muhammadiyah's education in other regions. But it can be ascertained that the most social organ that has an educational charity in Southeast Sulawesi is Muhammadiyah. The historical record as contained in the book of History of the National Awakening of Southeast Sulawesi, it is stated that Muhammadiyah encroached on this region beginning in 1929/30. ${ }^{9}$ And one of the areas that can be seen as the starting point of Muhammadiyah'srelation with the people of Southeast Sulawesi is Kolaka. This view is very logical considering that the early initiators of Muhammadiyah in this region generally came from South Sulawesi, while the Kolaka area is a region directly adjacent to South Sulawesi, where most of the population is from the South of Sulawesi region.

In reality Muhammadiyah and education are like two sides of a coin that are very difficult not to mention impossible to separate. Therefore, wherever Muhammadiyah grows and moves, its management will always think, move to create an educational institution. Likewise in Southeast Sulawesi, since the beginning of contact with the Southeast Sulawesi region, Muhammadiyah's movement in the field of education has been seen. In the book The History of the National Awakening of the Southeast Sulawesi Region: It was stated that in 1930 in Muna two Muhammadiyah schools had been established dedicated to the local community, as well as an effort to channel Islamic values and nationalism plus stemming from the rapid flow of Criticization. This institution was initiated by Muhammadiyah activists, some of whom were the sons of Muna who were very militant against colonial hegemony. Muhammadiyah succeeded in establishing two schools in Raha led by La Ati and La Kare leading schools in Mabohi. ${ }^{10}$

The seeds of Muhammadiyah's existence in Kolaka historically began to be distributed in 1930. The presence of Muhammadiyah in this area was called the initial milestone of the entry and growth of the modern Islamic movement. As in other areas, Muhammadiyah in

\footnotetext{
${ }^{9}$ Depdikbud, Sejarah Kebangkitan.....h. 104

${ }^{10}$ ibid
} 
Kolaka was transmitted by agents who generally came from teachers. These teachers were generally employees of the Dutch East Indies who were assigned to foster schools in the local area. With the professional background of the Muhammadiyah agents in the early period as mentioned, it is very logical that later Muhammadiyah would grow up in this area with a charitable educational effort. Even though North Kolaka, which was in the early stages of the establishment of Muhammadiyah, was still part of the Kolaka Regency, this region was not spared or quiet from Muhammadiyah cadres. The potential and quality of Muhammadiyah cadres who reside in this region are not only from the "elite" but also have a strong passion to develop Muhammadiyah activities and so on. Some Muhammadiyah cadres who later became known as Southeast Sulawesi leaders, who at the time developed Muhammadiyah branches in North Kolaka included BrigjenMajidYunus, M.AliKamri and PettaRukka. They developed Muhammadiyah especially in Wawo and Tolala areas. ${ }^{11}$

The establishment of educational institutions in North Kolaka by Muhammadiyah exponents was certainly not something that appeared suddenly, but was closely related to the socio-cultural conditions of the local community at the time the educational institution was established. Geographically North Kolaka is an area located at the northernmost tip of Sulawesi-Southeast which is directly bordered by South Sulawesi. The distance of this area from the center of Kendari City as the Capital of Southeast Sulawesi is more than 300 $\mathrm{km}$., With good road infrastructure conditions, the travel time to this area is around 6 to 7 hours. This condition is very different from the situation 30 or 40 years ago, where local residents aiming for the city of Kolaka can only be done or traveled by sea, considering that the land route has not yet broken down as can be seen now. In this context, it can be stated that the social geography of the people of this region could only break its isolation around 30 or 40 years after the independence period. Namely after the establishment of a road connecting the Lasusua and its surroundings (now the Capital City of North Kolaka) with Kolaka which was once the capital of the North Kolaka Regency. Such geographical conditions, of course, have implications for the availability of social facilities and infrastructure,

${ }^{11}$ Ibid., h. 94 
including education infrastructure. Until this research was conducted, researchers have not found data on the amount and type of education infrastructure built by the government and the private sector around the North Kolaka region after the independence period until 20 or even 25 years afterwards. But the most certain in history is known that this region after the period of independence until 1965 is known as one of the bases of the concentration of DI / TII forces led by KaharMuzakkar.

If it refers to the social and political historical realities surrounding North Kolaka, at least 25 years after the proclamation of independence, which was marked by the making of several regions in the area as a bastion of DI / TII forces, then logically this region could be declared as a place that was not quite safe from the social political side. This social background has so much influence on the development of the world and educational institutions in the related regions. Can be imagined by the social situation marked by armed political conflict between the national soldier (TNI) representing the State and the separatist forces DI / TII, the social life of the people around the area is not only disturbed, but also in a dilemma and a situation full of tension. The position of society in general becomes problematic because its support is not only contested by the warring parties, but is also at the same time suspected. With a situation of uncertain social and political tension, it seems that it will be very difficult to find educational institutions or groups of people who can think seriously to act and give their power and abilities to the general public.

In the tense social and political life conditions of the community, Muhammadiyah with all its limitations tries to unravel the needs of the community in the field of education. Muhammadiyah's activity in the field of education seems to be a historical "taqdir" for its members that they absolutely must live. The view that says where there is Muhammadiyah it is almost certain that there are educational institutions, does not seem to be an exaggeration. No exception in Southeast Sulawesi, Muhammadiyah educational institutions can also be found in almost all regions. The history of Muhammadiyah education in this region is as long as its existence, because it becomes a necessity in every place where Muhammadiyah cadres want to establish Muhammadiyah, so as proof of its seriousness in being Muhammadiyah, then in that place a charity must be established in 
Muhammadiyah. Therefore, in the territorial context of Southeast Sulawesi the charitable efforts in the field of education established by Muhammadiyah can be witnessed starting from the border of Southeast Sulawesi and South Sulawesi in the North of Kolaka to the easternmost island facing the Banda Sea, the building of Muhammadiyah educational institutions can be witnessed .

In North Kolaka as in other regions, the Muhammadiyah community also dedicates itself to educating the nation's life through the establishment of charitable business in education. A number of informants mentioned that the Muhammadiyah educational institutions present in this region basically existed in the period before independence, however historical data on related matters was very difficult to find. Valid data that can be accounted for to date informs that the Muhammadiyah educational institution that was first established in North Kolaka was the Muhammadiyah Madrasah (MI) Muhammadiyah in TojabiLasusua Village. The establishment of MI MuhammadiyahLasusua was spearheaded by $H$. Muhammad YasirAndiMallapiseng who at that time was a member of the People's Consultative Assembly in 1968 assisted by his brother H. Ramli. MI MuhammadiyahKolaka Utara by a number of community leaders in the region is seen as one of the oldest Islamic educational institutions in North Kolaka. ${ }^{12}$

Through the MI he built, Muhammadiyah seeks to develop the character of local children through education to create a generation that is not only intellectually intelligent but also has a social sensitivity based on the noble values of the teachings of Religion. One of the values that is strongly emphasized to be transmitted by the Muhammadiyah community in this region through the educational institutions it establishes is the value of tauhid. Madrasah IbtidaiyahMuhammadiyahTojabi has a special program that makes the value of tauhid as the basic foundation of the curriculum that is concrete manifested in the entire learning process. The curriculum is designed so that the values of monotheism can animate the whole subject; learning mathematics, science, language and other materials

12 Information was obtained through in-depth interviews with the management of Muhammadiyah North Kolaka Regional Lead ; H. Masmur Lakaihena. 
are oriented to re-unite the potential of monotheism, foster, and actualize it in everyday life. ${ }^{13}$

In addition to establishing MI Muhammadiyah Latjobi in Lasusua, in 1984 Muhammadiyah established the Muhammadiyah Middle School in Majapahit Village, a village that could be said to be the northernmost village of the Southeast Sulawesi region. The establishment of Muhammadiyah educational institutions in the outermost regions or villages was closely related to the social context of the community, namely the large number of local village communities at that time who had difficulty in obtaining educational services. So to respond to the educational desires of village children after completing education in elementary schools, Muhammadiyah through a number of cadres facilitated the establishment of SMP MuhammadiyahMajapahit. Because the pace of secondary education services in the surrounding villages at that time, so this school was forced to accommodate students from neighboring areas, even this institution facilitated education for young people who had previously dropped out of school because of the distance to go to secondary education. $^{14}$

The MuhammadiyahMajapahit Junior High School was founded on land which was partly waqf land and the rest was liberated by buying neighboring land through infaq and shadaqah movements run by local Muhammadiyah cadres. This school was initiated by $\mathrm{Hj}$. Syamsulhurryah and supported by the government, religious leaders and community leaders. As the representative of the government at that time was H. SuaibKasra who was the District Head of Lasusua. Whereas the support from the community was represented by Muhammad Arfah, Abdul Razak, H. Sonkeng and Abdul Panggolo who endowed a plot of land to become a school. In addition to the names mentioned above a Muhammadiyah resident named UstadBurhan then donated his clove garden to Muhammadiyah Middle School. It did not stop there, it seems that Muhammadiyah's social efforts continued, in 1988 the Muhammadiyah movement in the field of education through autonomous organs in particular, namely Aisyiyah, established Aisyiah Kindergarten. This institution was also initiated by local Muhammadiyah cadres including $\mathrm{Hj}$.

\footnotetext{
${ }^{13}$ ibid

${ }^{14}$ Muhtar Badawi, interview.
} 
Syamsulhurriyah. Based on the latest data obtained from the Aisyiyah Report of the North Kolaka Region, the number of kindergartens that Aisyiyah has built is now 10 (ten) units. ${ }^{15}$ To complement the educational facilities of Muhammadiyah in this region, then in 2017 or after 35 years of the establishment of the MuhammadiyahMajapahit Middle School, then the MuhammadiyahMajapahit IT High School was established. The establishment of this school was led by a Muhammadiyah cadre named MuhtarBaedawi.

The presence of the Muhammadiyah Islamic School in the region during the 1960s, followed by the establishment of junior and senior high schools was the social response of the Muhammadiyah community to the social atmosphere surrounding the local community. If in 1984 when Muhammadiyah established a junior high school in Majapahit, this school had accommodated the hopes of a number of children from various villages who wanted to continue and increase their literacy levels to the level of secondary education as mentioned earlier, then what was the state and condition of education in this region in 1960 -an. With the geographical conditions that are very difficult to travel through the land route to the city of Kolaka, plus the socio-political atmosphere that is not yet fully conducive, it can be expected that people in this region in those years became very difficult to get educational services. Thus, the presence of basic education institutions that were fostered by Muhammadiyah in Tojabi in the 1960s was certainly very helpful to the surrounding community to increase the intelligence of the local children. In this context, it is not excessive to state that this organ has a significant role in educating the lives of the nation's children who have grown up in the North Kolaka region, especially in Tojabi and Majapahit.

\section{Discussion : Appreciation and Criticism}

In the present context the establishment of Muhammadiyah educational institutions in North Kolaka as described may not be anything special, given the mushrooming of the establishment of various educational institutions ranging from kindergarten to tertiary level. However this is not the case with the context of the 1960s and 1980s. In the past 30 or 50 years the social and cultural atmosphere of

${ }^{15}$ Aisyiyah North Kolaka Regional Leaders Report at the Aisyiyah Regional Leadership Meeting, Kendari, 
the people of North Kolaka was not yet established. The condition of the terrain and the socio-cultural structure of the people of North Kolaka at that time was inversely proportional to what appears now. In terms of the social history of the 60 s this region was not only a DI / TII petilasan area but also at the same time as one of the strategic centers of residential concentration of the DI / TII group. So that in these conditions it can be ascertained that the people who reside in this place live in social and mental conditions that are loaded with tension and threats. In these circumstances it will be very difficult to think let alone establish educational institutions.

Vulnerable control, geographical conditions and potential conflicts as already mentioned are all variables that are undoubtedly considered to state that the efforts of the Muhammadiyah community to establish educational institutions are worthy of appreciation. Considering that at that time it was very rare not to say that there were no social communities in the North Kolaka area who voluntarily agreed to dedicate themselves, their time, energy and wealth to provide educational services when these services were very rarely available and at the same time very needed. According to Syamsulhurryah, the movement to establish a Muhammadiyah educational institution in North Kolaka carried out by Muhammadiyah cadres is a movement based on love for fellow children of the nation. The love movement of the nation is a manifestation of the implementation of the faith of a Muslim who always strives to empower others to stand in line with other nation's children and at the same time have competitiveness in the future. He further stated: that aside from being a form of Muhammadiyah's love for the children of the nation, the movement and activity of the Muhammadiyah cadres in establishing educational institutions is also a movement of love towards the Muhammadiyah organization. ${ }^{16}$

The existence of the Muhammadiyahschool as a socio-cultural phenomenon is interesting to study considering that there are many existential differences with other private school institutions. One of the fundamental differences that can be shown between Muhammadiyah schools and other private educational institutions is the ownership side. In terms of ownership, private schools are generally controlled or owned by groups of people listed as founding

${ }^{16}$ Syamsul hurryah, interview 
bodies in the notarial deed of formation, but this is not the case with Muhammadiyah Educational Institutions. Muhammadiyah educational institutions as a whole are purely social initiatives from Muhammadiyah cadres who live in an area, whether they are permanent residents or not. The establishment of the institution is a social conscience, using private funds from the results of savings or sometimes endowments, but the ownership is later handed over to the local Muhammadiyah leadership. Therefore, in general the Muhammadiyah education institutions financing initially rests on who or the individual initiates, however the initiator referred to is not the owner even though the initiator may be the person who sacrificed the most, both funds, energy, time and mind.

The above description can also be seen in educational institutions established by North KolakaMuhammadiyah. Which if you want to conclude all the initiators of the growth of educational institutions in the region are not the institution's owners. Although the initiators were in a long enough time and went through difficult times full of challenges, painstakingly set up schools to further with full sincerity the full ownership rights to Muhammadiyah were granted. It was in this context that the Muhammadiyah education movement in North Kolaka as described was a philanthropic social movement based on collectivity and sincerity.

Social activities based on collectivity and sincerity can be said to be typical symptoms of Muhammadiyah. This phenomenon stands out in the existence of Muhammadiyah which is very likely to be a distinguishing characteristic of other organizations. The social philanthropy movement that is run by Muhammadiyahcadres, can be said as a movement to melt away the ego of individual ownership towards collective ownership. This view is not without reason, bearing in mind that each of the charitable activities carried out by Muhammadiyah residents, however, the activity was built on private funds, but the ownership is not private and does not constitute the inheritance of the family concerned but constitutes the wealth of the organization. That awareness has become a collective awareness shown by Muhammadiyah residents. For Muhammadiyah residents, this reality has become a historical destiny for them, that their direction in building an educational institution is not through individual channels, but through an organizational system. 
With that in mind, the movement model carried out by the Muhammadiyah exponent in assisting the community in the field of education as described. It seems clear that the movements of the social activities carried out by Muhammadiyah, both in Latjobi and in Majapahait, were all oriented to unravel the tangled threads of social problems in the field of education experienced by the community at the time. Muhammadiyah's social efforts to provide a basis for monotheistic thinking as the main idea underlying all learning systems in MI Latjobi as well as in Majapahit, are concrete efforts to build culture and instill the value of independence. Because as is known that one of the main elements of the vision of monotheism is to hang hope in the Almighty Substance (Allahu al-shamad). Therefore, the journey of Muhammadiyah North Kolaka's social activities since its inception, is more likely to establish educational institutions that are oriented as locations or places to build the mindset of the community rather than acting as a charity institution.

Based on the description above, then paradigmatically the Muhammadiyahphilatropical model shows more on the color of philanthropy for social justice. The social philanthropy paradigm in its implementation is carried out collectively. The model of social philanthropy based on collectivity can be stated as a typical model of the Muhammadiyah social movement whose cultural seed has been sown by KH. Ahmad Dahlan. That is why this culture has its roots in the tradition of Muhammadiyah's hereditary citizens. If examined historically, social philanthropy based on collectivity that lives in the culture of Muhammadiyah is a brave breakthrough KH. Ahmad Dahlan. A breakthrough that seems simple if measured by the reality of the philanthropic movement that is growing in contemporary space, but the breakthrough becomes extraordinary because the model grows in the middle of Muslims who are still framed by traditional culture which relies more on local groups such as pesantren institutions with the role of the kyai. very dominant as an informal leader. Muhammadiyah's educational philanthropic social movement is clearly a modern phenomenon of the 20th century, which was intelligently adapted by KyaiDahlan as a "washilah" (tool, instrument) for achieving Islamic goals, ${ }^{17}$ and then inherited with full sincerity by

\footnotetext{
${ }^{17}$ Suara Muhammadiyah, Meneguhkan dan Mencerahkan "Geliat Muhammadiyah Asean" edisi no. 16 Agustus (Yogyakarta 2017).
} 
the successors of Muhammadiyah in each region. Muhammadiyah members who inherited a collective philanthropic-based social philanthropic system and model that lives at the present time can be declared as social groups that also have the courage as demonstrated by Dahlan. How could it not be that in a world filled with a capitalist system that was oriented towards material benefits of a personal nature, there were communities that gave away their time, energy and funds not for their own property but for the organization.

That one of the strength bases of Muhammadiyah which is commonly known is social collectivity with a high level of solidarity of its citizens. The spirit of collectivity combined with the readiness to donate through organizational channels makes this organization exist across borders. No wonder that almost all of the regions in the form of Muhammadiyah's charitable efforts can be seen. However, what Muhammadiyah exponents need to realize immediately is that the reality of a time that is always changing, even the changes are sometimes very difficult to predict, makes every individual, social group forced to surrender and sink in the swift flow of the waves of information technology. This view is not an illusion, learning from the case of various large companies that have been thrown down like Nokia, UBER in the case of Indonesia as a result of the presence of Grab and Gojek, has become a valuable lesson. Visible in the eyes of every eye now, that how the superiority of the past that is not renewable with contemporary management is very possible to bend the knee before the social groups of newcomers, as a result of their inability to follow the rhythm and rhythm of progress brought by renewable social movements.

The reality described above, the phenomenon also impacts on the world of education which is one of the core business of Muhammadiyah. It seems that many things that used to be something extraordinary was done by Muhammadiyah in the world of education, now they become ordinary or even transformed into worthless or glimpsed. In this context as an effort to build the sustainability of the Jariyah movement of the founders and layers of the foundations of Muhammadiyah education in North Kolaka, the Muhammadiyah educational institutions in North Kolaka must always be prepared to revitalize themselves to renew their approach in the world of education. This is important, bearing in mind that with the opening of the North Kolaka region coupled with increasingly globalized access 
to information, newcomers with new management in the world of education will come into play in areas that were previously unobtrusive in order to compete for the sympathy market. This condition requires Muhammadiyah to make a paradigmatic leap in the management of educational institutions, if not, then it is not impossible that Muhammadiyah educational institutions that once existed will become memories or become historical fossils.

The challenges of Muhammadiyah's educational institutions now and in the future will be more severe, both in terms of institutional management and in the aspects of cultural values encountered. That at one particular time the Muhammadiyah educational institution in North Kolaka had donated a ray of light to the efforts of enlightening the minds of the local children, was an inevitable reality. However, the dynamism of cultural dynamism which is stretched as it seems clear, then requires Muhammadiyah to think again, in order to sincerely abandon the old paradigm in managing the educational institutions it fosters, while immediately actively collaborating with the dynamics and demands of the times in the world of education. At the same time Muhammadiyah's educational institutions are also expected to remain as a moral bulwark, which presents a meaningful filter in counteracting the swift flow of the cultural movements of individualism, materialism and hedonism that plague.

\section{Conclussion}

Referring to the data described, it can be stated that the pattern of Muhammadiyah education philanthropic movement in North Kolaka is in the category of social philanthropy. Muhammadiyah's educational philanthropic movement in North Kolaka, although the volume is still very limited when compared to similar movements in other regions, the philanthropic social movement is a social cultural fact which is undoubtedly to be appreciated. Imagine, the movement of the education movement has been present in a social space that historically was geographically isolated and prone to social historically political politics. In such limited conditions, in a period where the eyes of social movements are generally still fast asleep and while the hands of devotion are still rigidly gripped, Muhammadiyah with all its limitations greets rural children who are far from educational services, in order to provide literacy water as a solution to 
thirst for education they feel. The presence or even the ability of Muhammadiyah to fulfill literacy expectations for a number of rural children at the time of the scarcity of education in North Kolaka and or at present is the fruit of collective sincerity. The construction of collective excitement was channeled philanthropically by Muhammadiyah cadres in North Kolaka on the foundation of humanitarian principles which are rahmatanlilalamin, with a common goal to educate the life of the nation. These efforts in a political context might also be interpreted as wordless nationalism, which is very rarely filtered through preaching because they believe that the spirit is not merely voiced but is certainly practiced by Muhammadiyah. However, along with the development of culture and stretching increasingly competitive era that penetrated the world of management of educational institutions, the Muhammadiyah was also demanded to immediately revitalize the management of its educational institutions in North Kolaka, if it did not want to be a historical fossil.

\section{REFERENCES}

Bappenas. (2018). "Peran Gerakan Filantropi untuk Keberlanjutan Organisasi Masyarakat Sipil", Laporan Akhir Kajian, (Desember,2010),BabIII.Tersediadihttp://ditpolkom.bappenas.g o.id/diakses20 November.

Departemen Pendidikan dan Kebudayaan. (1978), Sejarah Kebangkitan Nasional Sulawesi Tenggara, Jakarta: Depdikbud.

Departemen Pendidikan dan Kebudayaan. (1999). Kamus Besar bahasa Indonesia, Jakarta: Depdikbud.

Huda Syamsul. (2019). Muhammadiyah Sebagai Gerakan Pendidikan, TARLIM :JurnalPendidikan Islam, Vol.2, No. 2.

Husni Rahim. (2001) "Arah Baru Pendidikan Islam di Indonesia" Jakarta: Logos Wacana Ilmu.

Latif, Hilman. (2017). Melayani Umat: Filatropi Islam dan Ideologi Kesejahteraan Kaum Modernis, Yogyakarta: Suara Muhammadiyah.

Latif, Hilman, dkk. (2015). Prilaku dan Potensi Filantropi Warga Muhammadiyah (Survey di 11 Kota Besar Indonesia, (Yogyakarta: Lembaga Penelitian, Publikasi dan Pengembangan Pendidikan UMY). 
Mafidin. (2012). Studi Literaturt entang Peran Muhammadiyah dalam Mengembangkan Pendidikan Islam di Indonesia, Jurnal Tarbawi, Vol.1, No.1.

Syafaruddin. (2005). “ Manajemen Lembaga Pendidikan Islam” Jakarta, Ciputat Press.

Suara Muhammadiyah meneguhkan dan mencerahkan. (2015). "Dinamisme Kader Muhammadiyah" Edisi No. 09 Mei, Yogyakarta.

https://www.kolutkab.go.id/sejarah-kolaka-utara, Mengenal Latar Sejarah, Nama dan Bahasa, Suku di Kolaka Utara

Room, Muhammad. (2006). "Implementasi Nilai- Nilai Tasawuf DalamPendidikan Islam SolusimengantisipasiKrisis Spiritual si Era Globalisasi".

Suara Muhammadiyah Meneguhkan dan Mencerahkan. (2015).“Komitmen Gerakan Pencerahan" edisi no. 15 Agustus, Yogyakarta.

Suara Muhammadiyah Meneguhkan dan Mencerahkan "Geliat Muhammadiyah Asean" edisi no. 16 Agustus, Yogyakarta ,2017

Widyanta, A. (2002). Probem Modernitas, Yogyakarta: Cinelaras Pustaka Rakyat Cerdas.

Utama, Abdul Alimun. (2017). Sejarahdan Perkembangan Lembaga Pendidikan Muhammadiyah di Kabupaten Sumbawa Nusa Tenggara Barat tahun 1940-2014, PROFETIKA JurnalStudi Islam, Vol. 18, No.1.

Yusra, Nelly. (2018). Muhammadiyah: Gerakan Pembaharuan Pendidikan, POTENSIA, Jurnal Kependidikan Islam, No. 1, Vol. 4. 